$$
\begin{array}{r}
\text { Irina M. Sakhno } \\
\text { Ph.D. in philology } \\
\text { Professor of the department of the theory and history of culture, } \\
\text { liberal arts and humanities branch of the faculty of humanitarian and social sciences } \\
\text { the Peoples' Friendship University of Moscow. } \\
\text { e-mail: drsachno@msn.com } \\
\text { Russia, Moscow } \\
\text { ORCID 0000-0002-5510-6684 } \\
\text { ResearcherID: B-2047-2016 } \\
\text { Scopus Author ID: } 57196349789
\end{array}
$$

\title{
Self-portrait As a Strategy of Female Biographical Writing (The Italics are Mine by Nina Berberova and A Girl Rolling a Hoop by Olga Gildebrandt-Arbenina)
}

Summary. The article focuses on the problem of the morphology of the self-portrait in the structure of female autobiographies of the Silver Age. Nina Berberova's autobiography and Olga Gildebrandt-Arbenina's diaries, viewed as self-portraits unfolding in time, are the objects of analysis. On the one hand, the architectonics of self-portrait is related to the development of female subjectivity in the situation when a woman, being in male culture, has to express her identity through 'italics' and 'diaries'. On the other hand, it is related to intermediality as a typical feature of early $20^{\text {th }}$-century culture when discursive interconnections in a verbal piece of art were based on the semantic codes of other arts. The author considers the problem of visualization of the verbal in the semantic structure of self-portrait. Like a painter or photographer, the female author constructs new visual rhetoric marking her self-identity and recognizing herself in the Other inside the mirror of self-portrait and the camera lens. Hence the prioritized visual strategies of self-portrait representation: 1) a mirror as a metaphor of autobiographical memory; 2) a camera-lens and recognizing oneself in the Other.

Keywords: autobiography, self-portrait, the verbal/the visual, 'a person in a mirror', plastically expressive portrait, 'structural symbolics', mirror optics, visual rhetoric, photography, camera lens, perspective, vanishing point.

The need for self-description is an acknowledged universal of modernist culture. A biographical text signifies an author's desire to discover subjectivity in a dialogue with him or herself and the others. Paul Ricoeur drew attention to this semantic ambiguity of narrative identity in autobiography, expressing the idea of "identity" (identity to oneself in time) and "the self" ("I" myself). [1] Therefore, the "I" is constituted by a sequence of subjective identifications and self-reflections: "Even when Van Gogh draws a chair," the philosopher notes, "he portrays a person: he projects an image of a person on the canvas, that is, the one who envisions this world" [2]. Female autobiography is not only 
a comprehension of personal history in the "subjectivity chronotope" [3]. In contrast to a narrator-voyeur who seeks to peek at what is hidden and secret, a woman creates her type of biographical writing publicly exposing the innermost zones of intimate and confessional experience. Overcoming cultural and anthropological restrictions and bodily taboos, a woman expresses a new identity that does not fit into the male/ female dichotomy. [4] Reflecting on the "female letter" in the article "The Laughter of Medusa", Helen Siksu addresses women with an appeal: "Portray yourself, portray yourself!". Bodily writing, when the body is inscribed in the text, generates a new bodily experience of verbal and visual discursive practices: "A woman must portray herself: she must write about women and attract women to the writing process, from which they have been rejected as cruelly as from their own body for the same reasons, through the same laws and the same fatal purpose. A woman must put herself into the text as if into the existing world and into human history, having made an independent move" [5].

Bodily writing, when the body is inscribed in the text, generates a new bodily experience of verbal and visual discursive practices. In this way, a gender approach to the study of female autobiography is articulated in literary feminist criticism [6]. In autobiographical writing, a woman appeals to female bodily and sexual experiences; the specificity of female subjectivity is defined as a convention of the self-representation of the female "I" and internal "affect history" [7]. Leaving feminist discourse and gender research reflections as marginal notes, we turn to the morphology of the self-portrait in the structure of the female autobiography of the Silver Age. Self-portrait, as an author's inquiring peering into herself or himself, becomes a fact of self-identification and self-knowledge of the creator and the spy. Its architectonics are connected, on the one hand, with the formation of female subjectivity [8] when a woman, being inside a male culture, expresses herself through "italics" and "diaries". On the other hand, with intermediality [9] being a characteristic feature of the entire culture of the early twentieth century when discursive relationships in a verbal work were based on the interaction of semantic codes of other arts [10]. The synthesis of narrative and visual auto-representations, in our opinion, is the key to deciphering the autobiographical code. Philip Lejeune, stating the fact of early awareness in the history of the art of the portrait as a genre, complained about the lack of research on the verbal portrait in autobiography [11]. We are interested in the problem of visualizing the verbal in the semantic structure of a self-portrait, when, as if a painter or a photographer, a female author designs new visual rhetoric [12] and through the mirror of the portrait and lens marks herself and identifies herself in the Other. That having been said, we can determine the priority, in our opinion, of visual strategies for representing the self-portrait.

\section{A Mirror as a Metaphor for Autobiographical Memory}

The metaphor of mirroring as the leading ontological principle has already been formulated in ancient myths. Narcissus, glancing at his reflection, melted with self-love. 
Perseus, looking at the polished surface of the shield, killed Gorgon, a monster whose gaze is fatal to humans. Hera sent titans to little Dionysus-Zagreus, first luring him with rattles as well as a small mirror, and then killing him. The goddess Rey (Athena or Demeter) received the heart of Dionysus-Zagreus. She put the pieces of the body into a casket after which he "is again reborn to life." [13] The ambivalent nature of the mirror is described in these myths since the principle of mirror reflection is based on the principle of "resemblance/similarity" and "difference". On the one hand, a person sees his or her reflection in a mirror - the mirror double. On the other hand, since ancient times, a man has made a distinction, realizing that the reflection in the mirror hides as much as it shows [14], it is an optical illusion as evidenced by the inversion of the left and right. The mirror as an object of self-knowledge and a new reflective experience is studied by J. Lacan in his work The Mirror Stage as Formative of the Function of the I. Reflecting on the role of the mirror in a child's development, the philosopher considered the mirror as a symbolic matrix, a kind of identification and transformation which occurs with the subject when he or she appropriates a certain image for him or herself. The mirror stage is the most important moment in the formation of the structure of the subject, the first sketch of the $I$ and the incipience of the recognition experience. For Lacan, the fact that such recognition is fixed at the stage when a child is able to identify him or herself in the mirror is important. The mirror displays, makes obvious the process of self-generation through attitude to oneself, one's body, turning into a holistic experience. Here, the child first recognizes and acknowledges his image, appropriating it only when he believes that this image is his own, only belonging to him:

"This development," Lacan notes, "is experienced as a temporary dialectic, decisively projecting the formation of an individual into history: the mirror stage is a drama (the drama of establishing one's own identity, the $I$ ), the inner message of which is rapidly developing from insufficiency to advance and which for the subject, caught on bait of spatial identification, invents fantasies gradually moving from a fragmented image of the body to a form, which we will call orthopedic for its integrity - and, finally, with the armour of a certain alienating identity, which will mark with its rigid structure all its mental development" [15].

"I am like the other" and "the other is like me" is the basis of the narcissistic relationship of a person and his or her double. [16] Mirror narcissism manifests itself in the pleasure of contemplating one's own mirror reflection and discovering the Other in oneself. A mirror as a metaphor for autobiographical memory is a deep layer of memory, a trace of a long time ago: "The depth of the mirror is comparable to the depth of memory," E. Krasnukhin reflects upon the narcissism and mirror metaphor, "their general nature is the nature of repetition. Memory is a kind of a mirror, it reflects the past. Memories are a repetition of the pure past in the present. And the mirror, projecting before us the narcissistic objects of desire, turns them into memories in the sense that desire refers us to the type and ideal, to the original of the pure past. Like a mirror, memory is a deep and superficial form of reflection. Therefore, speaking of the narcissism of the mirror 
and the eroticism of memory, we find two of its forms - the recall of meaning and the haunting refrain of the empty signified". [17]

"A man in front of a mirror" is a universal metaphor in Mikhail Bakhtin's moral philosophy. The scholar analyzes the situation of mirror reflection in which the mirror is a kind of means of "self-objectification". This phenomenon is associated with the categories of the "other" which actually acts as the "I am the double." The phenomenon of mirroring, according to Bakhtin, is reflected in two different ways of experiencing oneself: a) "a primitive position of self-consciousness" contemplating one's own appearance, the "external" image; b) "self-awareness" from the perspective of the "Other": "A very special vision of one's appearance," Bakhtin comments, "is looking at oneself in the mirror [...]. We see a reflection of our appearance, but not ourselves in our appearance, the appearance does not hug me all, I am in front of the mirror, and not in it [...]. Indeed, our position in front of the mirror is always somewhat false since we do not have an approach to ourselves from the outside, here we also get used to some kind of uncertain, the possible other, with which we try to find the value in relation to ourselves, here we try to revive and shape ourselves from the other; hence the peculiar unnatural expression of our face which we see in the mirror and which we do not have in life." [18]

According to Bakhtin, the task of an artist working on a self-portrait is "purification of the expression of the reflected face". [19] And this is achieved provided that the authoritative artist-author defeats the artist-person. Starting from the 16th century, the use of a mirror in the self-portrait genre has meant that the face of each person is a meaningful text worth reading. Self-portraying using a mirror is sees as a way of selfknowledge - an inquisitive peering at oneself in a mirror signified the process of forming new optics and changing the way people feel about themselves. [20] A mirror reveals hidden traces and images, a complex system of allusions and metaphors, establishing a semantic identity and a new sign. A mirror and memory work in the conjugate territory of the reflected memory. A mirror articulates the idea of semantic identity, reflecting the "external person" [21]; memory "visually restores the past", [22] erasing its borders. A mirror in biographical prose is not only a metaphor for autobiographical memory but also a hidden signature of the author themself whose anonymous participation is manifested in recording the documentary fact of his or her own life. Let's turn directly to the texts. Two different strategies for auto-representation through a portrait are before us. Berberova's main task was "to find the structure of individual symbolism" [23] (KM: $264)^{1}$, to establish "the fact of knowing oneself and looking inside oneself" (KM: 29), "to decipher the meaning of reality inside and outside me" (KM: 104). An autobiography for a writer is, first of all, a "story about oneself" (CM: 29); thus, three forms of selfobservation are: a) a portrait as a view of oneself from the side; b) a sculptural-pictorial

1. Hereinafter in the text, the following abbreviations are used with the indication of the page: KM - Berberova N. The Italics are Mine. Autobiography. Moscow: Soglasiye, 1996; DKS - Hildebrandt-Arbenina O. A Girl Rolling a Hoop. Memoirs. Diaries. Moscow: Molodaya Gvardia, 2007. 

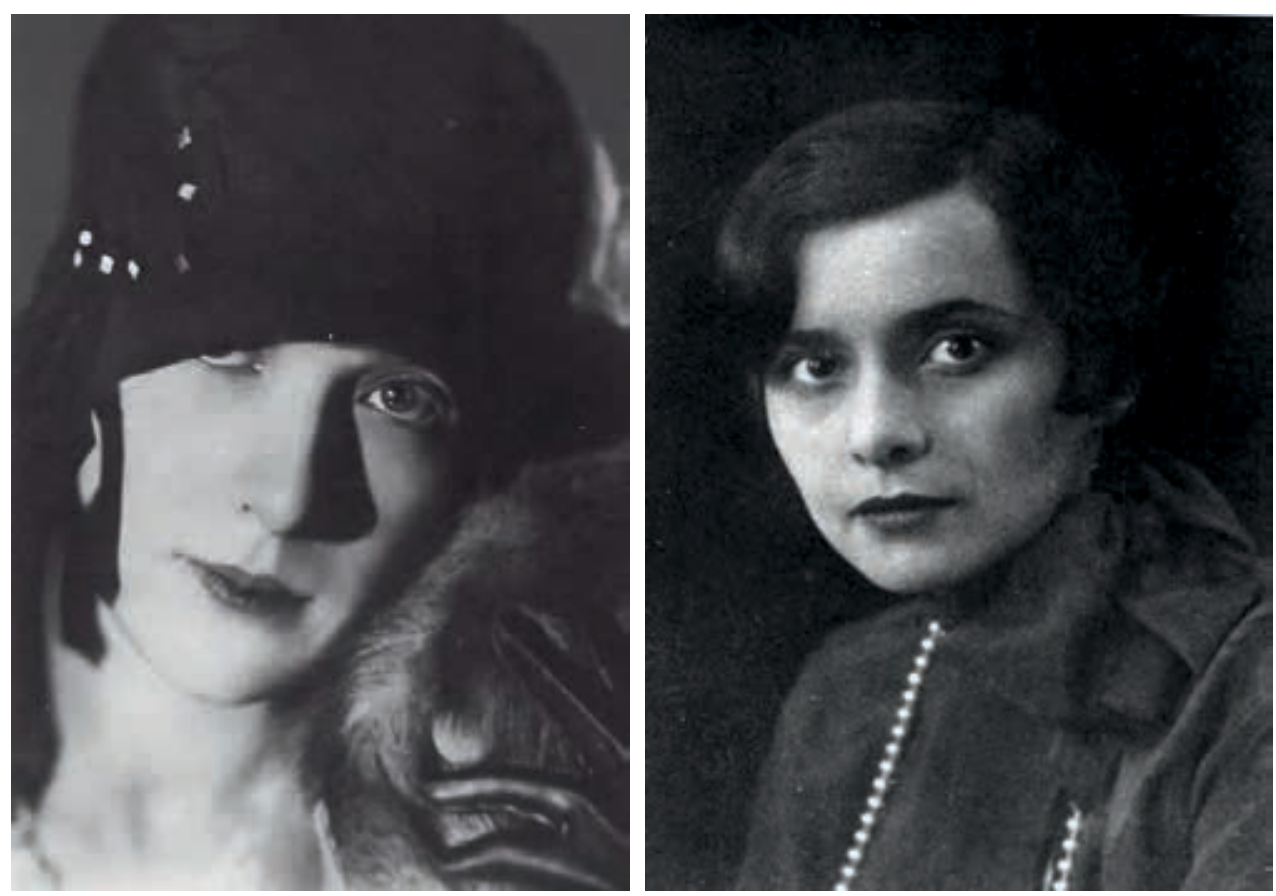

Nina Berberova and Olga Gildebrandt-Arbenina. Photos from the 1920 s.

Image source: http://ru.hayazg.info, http://gvardiya.ru/publishing/authors/olga_gildebrandt-arbenina

self-portrait in the space of mirror reflection; c) "structural symbolism" (Berberova's metaphor) as a reflection of the essential "I". Let's compare the first two:

"Before himself, the reader may already see a stern face, glasses, mustache, false teeth, gray, straight, short-cropped hair on the back of the head (thinning on the crown) and that boring, thick and truly "eternal" quill held in an arthritic hand with blue veins. The picture is wrong. Not only do I not have a mustache, but also not much eyebrows. In my youth, I had a pretty face without any expression; by the age of forty, my face became thin and very sad. And now, it's not for me to judge what it is. Yes, I do not really remember it now when I write. I only know that time has worked with an ax over my features: it has sharpened my chin, outlined my mouth, raised my cheekbones, and cut my cheeks. The forehead has become hard, and now the whole oval in its shadows lives a life much more intense than in the earlier photographs. However, my nose is still short." (KM: 31)

The main emphasis in this sadly ironic self-description is made on the intensity of the author's inner life. Berberova herself selects a very precise word - "self-change" (KM: 31). Another semantics of the portrait is manifested in the "idea of a fixed image" [24], when the author once sees his or her reflection - literally: "I am reflected" - during an intermission in the mirror of the Théâtre des Champs-Élysées: "It is hanging by the 
stairs and to the right and in it you see yourself for a long time when you walk towards it. There, in the depths of this mirror, I saw myself that first evening, my blue dress, with white lace, in the fashion of the day without sleeves and without a waist, legs in patent leather shoes, a knot of hair on the back of my head, thin arms. Khodasevich was next to me" (KM: 255). This establishes semiotic equality between the observer and the observed, between the author of the text and the author in the text. According to Lotman, a mirror as a visual text in a verbal space creates a "doubling effect" when mirror optics change perspective and point of view, transforming old cultural meanings. [25] The myth of Tobiah and the Angel play an important role in the visual labyrinth of autobiographical memory and personal symbolism [26]. A favourite plot in Renaissance painting is another way of self-portraiture for Berberova. Identifying herself with Tobiah and with the Angel, she sees a duality in herself - a gap, a "suture", and, according to the author, "the synthesis phenomenon in the world of antithesis" is manifested in this "campaign of small and large" (KM: 51): "Looking at Tobiah, I see myself carefully carrying fish, marching confidingly along the low horizon, one, two, one, two, shoes are tightly laced, a band is holding my hair so that the wind does not tousle them. I look at the Angel, and also see myself: sandals are cleverly clasping my feet, wide lobes of clothes are curling around my hips, my face is facing forward, as if on that figure they carve in wood and place on the bowsprit of a ship going on a long journey and which is the most vivid and constant image of my personal symbolism. [...] Tobiah is everything which is afraid and uncertain in me, which does not dare, does not know; everything which is mistaken, the doubts, everything that is hoped, everything that is sick and longing. And the Angel, one and a half times the height of a human, is everything else, including the delight of life and the feeling of physical health, and balance, and my immovability, and the denial of fatigue, weakness, old age. (KM: 253-254)

\section{A Mirror of a Photo Lens and Self-identification in the Other}

In Olga Gildebrandt-Arbenina's memoirs and diaries, we come across a different self-portrait strategy since, for her, memories were primarily a story about the Others. Berberova strived to tell about herself and to understand the meaning of her own life, hence the more likely male, analytical view of the world and positioning herself as an "internal" viewer. Olga Gildebrandt-Arbenina is a woman-muse: "a satin cat" (Gumilyov), "Gumilev's girl" (Yurkun), "a mansard muse" (Mandelstam): "I wanted to be a Woman and Creative power" (DKS: 214); however, "remained a shadow in someone's fate" (DKS: 175). Old age is disgusting, "but I have stopped being a woman, an artist too, so the conclusion is clear; why am I needed in the world?" (DKS: 215). For the author, the mirror becomes a witness to the fading beauty and fading youth, therefore the words "disgusting to look in the mirror" (DKS: 214) are read as a sentence of an unfulfilled fate. The female self-portrait in Hildebrandt-Arbenina's memoirs and diaries is constructed 
in a group portrait through the opposition of the $\mathrm{I} /$ the Others. The parallelism of the verbal and visual is manifested in a different visual metaphor - a mirror as the eye of a photo lens. The authenticity of photography and portrait was pointed out by Y. Lotman in his work A Portrait, written in 1993: "A portrait," he wrote, "is a painting that used to serve as a photograph when photography was not yet invented [...]. A proper name is between a photograph and a portrait, and this is reflected not only in the mystical but also in the legal identification of a person and his portrait" [27]. Thus, a photograph, having destroyed the traditions of mimetic aesthetics, began to meet the new needs of visual representation which were previously satisfied with the help of a mirror and a portrait, and "the camera became to be thought of the same as a painter's painting, a poet's quill, and a sculptor's cutter" [28].

Self-portrait characteristics in the memoir text are brief visual chronicles that capture a specific moment: "When a photographer sets the optical viewfinder, the line of aim goes through his or her eye, head and heart [...]. Photographing is my sketchbook," Henri Cartier-Bresson reflected on photography [29]. Hildebrandt-Arbenin, like a photographer armed with a camera, provides readers with documentary evidence of her beautiful youth. Unlike her paintings, presenting her early childhood ("My paintings are me in childhood, in early childhood" DKS: 214), in prose we see her portraits during the heyday and meeting with the best representatives of the Silver Age - and they are photographically brief: "I looked beautiful (could not look better, in my opinion); I had a big beautiful hat with a black currant, very natural" (DKS: 112); "I had a white light dress (fabric from an American parcel) and a large straw hat" (DKS: 128). As we can see, the main emphasis is on "how she looks" and how others look at her for the reason that the most important viewer for her is a man. [30] The mirror of a photo lens is the eyes of a palimpsest memory. Erasing layer by layer, the author appeals to the restored past, partially mythologized. Taking a picture means capturing a real story, giving importance and value to the object itself. That is why any portrait in a certain sense is a self-portrait of a photographer [31]: "Photographers," Susan Sontag notes, "describe their work as countless methods of mastering the objective world, and as a solipsistic expression of a separate "I". [....] If a photograph is directed to the world, the photographer means little; however, if it is the instrument of fearless incarnating subjectivity, the photographer is everything." [32] The construction of a female self-portrait in the text A Girl Rolling a Hoop... also occurs through a group portrait. The visual rhetoric here is different. Putting herself in the center, comparing and contrasting herself with the Others, Hildebrandt captures the experience of self-identification: "I was very young; however, by the strange coincidence of my fate I had already experienced the saddest things in my life - and quite strong joys and hobbies, although I was strictly upbrought, I was often sick and studied a lot. He (Gumilev) later told me that he immediately rushed to find out who I was. "This is Balmont's sister." I was always confused with Anya Engelhardt, although she was not like me - more dark-haired, brown-eyed, with Mongolian cheekbones, more lively and, from my point of view, much prettier! I could probably have looked more 
like Nix Balmont, her brother - he was red-haired, green-eyed, with a light pink face and a facial tic - I really liked the latter in him [...]". (DKS: 100)

Thus, a discovery of the external and "the internal landscape" [33] in the mirror of reflected memories is made in a self-portrait. As an author and observer, a woman distances herself from the past, creating a kind of a linear perspective, designed to optically change points of view and create an illusion of three-dimensional depth. A mirror and perspective, forming an inseparable pair since Leonardo da Vinci, Alberti, Brunelleschi and others, embodying a new symbolic [34] and spatial vision, allowed the author of the autobiography to find the vanishing point on the horizon when the eye, as if a movement of a lens, visually restored only the past of the author; however, it found a trace, an imprint of his or her stay in the biography of the Other. In this vanishing point of infinity or the vanishing point of the past, at the funeral of Gumilyov, there was a minute meeting of the two heroines, Nina Berberova and Olga Gildebrandt-Arbenina, who described this meeting very laconically: "For some reason, I remember Berberova who came up and stood next to me. I didn't know her. We were of the same height and were wearing the same colour coat - deep red, which makes you think it really was cold - in a woollen cloth overcoat?” (DCS: 151)

\section{NOTES AND BIBLIOGRAPHIC SOURCES:}

1. On the priority of "I" in the concept of "I am different", a philosopher wrote: "[...] in order to have "the other" different from "I", it is necessary that the "I" itself exists. Paul Ricoeur. The Conflict of Interpretations: Essays in Hermeneutics (translated from the French by I. Vdovina) Moscow: "CANON", Kuchkovo Field Press-centre, 2002, p. 331.

2. Ricoeur Paul. 1996. Hermeneutics and Psychoanalysis. Religion and Faith. Moscow: Iskusstvo Publishing House, p. 18.

3. Pigrov, K.S. 2014. "A Personal Diary as a Philosophical and Anthropological Concept", The Power of Simple Things, Collected works under the editorship of S. Lishaeva. St. Petersburg: Aleteya, p. 218.

4. Refer to: Zherebkina I.A. "Feminist Theory of the 90s: the Problematization of Female Subjectivity", Introduction to Gender Studies. Part I: Textbook, Ed. I. A. Zherebkina. Kharkov: HTsGI, 2001; St. Petersburg: Aleteya, 2001, pp. 49-79.

5. Siksu, E. "The Laughter of a Medusa", Introduction to Gender Studies. Part 2: Chrestomathy, Ed. S.V. Zherebkin. Kharkov HTsTI, St. Petersburg: Aleteya, 2001, p. 799.

6. The most famous methodological works on the theory of "female literature" include the works of: Mary Ellmann's Thinking about Women, 1968; Ellen Moers's Literary Woman 1976; Sandra Gilbert and Susan Gubar's The Madwoman in the Attic: The Woman Writer and the Nineteenth-Century Literary Imagination, 1979; Rachel Du Plessis, Writing Beyond the Ending: Narrative Strategies of Twentieth-century Women Writers, 1985; Elaine Showalter A Literature of Their Own: British Women Novelists from Bronte to Lessing, 1977; collections "New Feminist Criticism: Essays on Women, Literature and Theory" (1985), "These Modern Women: Autobiographical Essays from the Twenties" (1978) and "Daughters of Decadence. Women Writers of the Fin de Siècle" (1984) edited by Elaine Showalter. The works on the methodology of "female reading" and "female writing" include the works by Toril Moi Sexual/ Textual Politics: Feminist Literary Theory, 1985; Mary Jacobus's Reading Woman. Essays on Feminist Criticism, 1986, as well as a book edited by her Women's Writing and Writing about Women, 1979; Shoshana Felman's What does a woman want? Reading and Sexual Difference, 1993; Alice Jardine's Gynesis: Women's Configurations and Modernity, 1985; a book edited 
by Nancy Miller The Poetics of Gender, 1986; as well as the works of French theorists Julia Kristeva, Lucy Yrigare and Helen Sixu. Refer to: I. Zherebkina. Feminist Literary Criticism. Electronic resource: http://www.owl.ru/library/004t.htm. (Date of access: 01/19/2019).

7. Zherebkina, I. Gender Issues in the Paradigm of Cultural Research. Electronic resource: http:// sbiblio.com/BIBLIO/archive/usmanova gender. (Date of access: 12/12/2018).

8. The new philosophical construction of subjectivity and the gender theory of subjectivity is analyzed in detail in the book by I. Zherebkina Subjectivity and Gender: the Gender Theory of the Subject in Modern Philosophical Anthropology. St. Petersburg: Aleteya, 2007.

9. To read more about the term "intermediality" refer to an article by A. Timashkov "On the history of the concept of intermediality in Russian and foreign science", Zmogus ir Zodis. Teoriniai Klausimai, Helsinki, No. 11, 2007. Electronic resource: http://www.biblioteka.vpu. 1t/zmogusirzodis/PDF/literaturologija/2007/tim21-26.pdf (Date of access 11/01/2019)

10. In the article "Methodology of Intermedial Analysis in the Light of Interdisciplinary Research", N.V. Tishunina offers several definitions. In a narrow sense, intermediality is a special type of intertextual relationships in a verbal work based on the interaction of art codes of different types of art. In a broader sense, it is the creation of an integral polyartistic space in the cultural system. Here is a more complete definition: intermediality is "a specific form of dialogue of cultures, carried out through the interaction of artistic images or stylistic devices that have a symbolic character for each particular era". N.V. Tishunina. "Methodology of Intermedial Analysis in the Light of Interdisciplinary Research", Methodology of Humanitarian Knowledge in the $21^{s t}$ Century Perspective, Materials of an international scientific conference. Symposium Series. Vol. No. 12. St. Petersburg, 2001, p. 153.

11. Lejeune $\mathrm{Ph}$. In defense of an Autobiography. Essays of different years, Translated by B. Dubina, Inostrannaya Literatura, 2000, No. 4. Electronic resource: http://magazines.russ.ru/ inostran/2000/4/lezhen.html (Date of access: 3/01/2019).

12. In our opinion, M. Grishakova works perfectly with this term, analysing V. Nabokov's prose., Grishakova M. Visual rhetoric of Vladimir Nabokov. / NLO, 2002 No. 54, pp.208-264.

13. "Epicurean Philodemus, a contemporary of Cicero, writes about the three births of Dionysus: the first - from his mother, the second - from the thigh of Zeus, and the third took place when Rhea put together pieces of his body torn by the titans after which he returned to life", Mircea Eliade. A History of Religious Ideas. Volume 1. From the Stone Age to the Eleusinian Mysteries. Chapter 1U. Dionysus, or the Return of the blessed God. Moscow: Criterion, 2002. Electronic resource: http://royallib.ru/read/eliade_mircha/istoriya_veri_i_religioznih_idey_tom_1_ot_ kamennogo_veka_do_elevsinskih_misteriy.html\#40960 (Date of 15/01/19).

14. To read more about the history of the mirror and its historical semantics refer to $\mathrm{S}$. Melchior-Bonnet's monograph "The History of the Mirror" / Preface by Jean Delumo. Translated from French by Y. Rosenberg. Moscow: New Literary Review, 2006.

15. Lacan J. The Mirror Stage. Network resource: http://www.gumer.info/bibliotek_Buks/Psihol/ lakan/st zerk.php (Date of access: 06/14/2019).

16. Lacan, J. 1999. Seminars. vol.2. Moscow: Gnosis Logos, p. 141.

17. Krasnukhina, E. "The Narcissism of Desire or the Metaphor of the Mirror in Philosophy", The Philosophy of Desire. Collected works, Ed. I.V. Cusin. St. Petersburg: the St. Petersburg State University Publishing House, 2005, p. 12.

18. Bakhtin, M. 1994. Author and Hero in Aesthetic Activity, Bakhtin M. The works of the 20s. Kiev: "Next", p. 113.

19. Ibid, p. 114.

20. This is embedded in the semantics of the word itself. To portray (from the French portrait, from the obsolete ortraire - to portray): a) take out, discover; b) to depict c) to describe with images, create a likeness. Refer about the etymology of the word portrait to V.N. Baksheeva's work "Russian Verbal Portrait: Lyrics and Prose of the late $18^{\text {th }}$ - the First Third of the $19^{\text {th }}$ Centuries". Thesis by Doctor of Philology. Moscow, 2000; Davletova Albina Robertovna. "Aesthetic Versions of a Female Portrait in the Short Stories of the $60-90$ s of the $20^{\text {th }}$ Century." Thesis by Doctor of Philology: 10.01.01 Moscow, 2007; Compare with obsolete, according to Dahl, portrait is a similarity, appearance, image, face.

21. Bakhtin, M. Author and Hero in Aesthetic Activity, p.116. 
22. Grishakova, M. 2000. "On Some of Vladimir Nabokov's Allusions”, The Culture of the Russian Diaspora: Nabokov-100. Moscow, p. 28.

23. The following abbreviations with the indication of the page are used in the text: KM-Berberova N. The Italics are Mine. Autobiography. Moscow, Soglasiye, 1996; DKS - Hildebrandt-Arbenina O. A Girl Rolling a Hoop. Memoirs. Diaries. Moscow: Molodaya Gvardia, 2007.

24. Levin Y.I. "A Mirror as a Potential Semiotic Object", Levin Y.I. Selected Works. Poetics and Semiotics. Moscow: Languages and Culture School, 1998. p. 563.

25."However, a mirror can play another role: by doubling, it distorts and therefore exposes the fact that an image, which seems "natural", is a projection carrying a certain language of modeling. The theme of the double is a literary adequate motive of the mirror. Just as the world behind the looking glass is a strange model of the everyday world, the double is a strange reflection of a character. By changing the image of the character according to the laws of mirror reflection (enantiomorphism), the double becomes a combination of features, allowing you to see their invariant basis, and shifts $\langle\ldots>$, which creates greater opportunities for artistic modeling." Y. Lotman. A Text in a Text, Y. Lotman. Articles, notes on the speech. 1. "General Problems of Art", Y.M. Lotman. On Art. St. Petersburg: Iskusstvo, 1998, p. 433.

26. For further details, see: Bernen S., Bernen R. Mythological and Religious Motifs in European Painting of 1270-1700. St. Petersburg: Academichesky Project, 2000. Pp. 234-236.

27. Lotman, Y. "A Portrait", articles, notes, speeches. 11. Fine art, Y.M. Lotman. On art. St. Petersburg: Iskusstvo, 1998, p. 500.

28. Nurkova, V.V. 2006. A Mirror and Memory. The Phenomenon of Photography. Cultural and Historical Analysis. Moscow: RGGU, p.125.

29. Cartier-Bresson A. Imaginary Reality. Essay. St. Petersburg: Limbus Press, K.Tublin Publishing House, 2013, p.15.

30. Reflecting on the function of the mirror in the history of painting, J. Berger articulates the idea of a woman as an object and a spectacle: "The real function of the mirror was different. The mirror was necessary for a woman to treat herself, mainly and first of all, as a spectacle". J. Berger. The Art of Seeing, Translated from English by E. Shragi. St. Petersburg: Cloudberry, 2012, p.60.

31. Sontag S. On Photography. Moscow: Ad Marginem Press, 2013, p. 161.

32. Ibid.

33. Ibid, p. 161.

34. On the symbolic nature of perspective, see E. Panofsky, Perspective as a Symbolic Form. St.Petersburg: Azbuka Classiki, 2004. 


\section{Ирина Михайловна Сахно профессор кафедры теории и истории Российского университета дружбы народов e-mail:drsachno@msn.com Россия, Москва \\ ORCID 0000-0002-5510-6684 \\ ResearcherID: B-2047-2016 \\ Scopus Author ID: 57196349789}

DOI: $10.36340 / 2071-6818-2019-15-4-43-62$

\section{Автопортрет как стратегия женского биографического письма ( Н.Берберова «Курсив мой» и О. Гильдебранд-Арбенина «Девочка, катящая серсо»).}

Аннотация. В статье исследуется проблема морфологии автопортрета в структуре женской автобиографии Серебряного века. Объектом анализа становятся автобиография Н.Берберовой и дневники О.Гильдебранд-Арбениной как автопортреты, развернутые во времени. Архитектоника автопортрета связана, с одной стороны, со становлением жен-ской субъективности, когда женщина, находясь внутри мужской культуры, выражает себя через «курсив» и «дневники». С другой - с интермедиальностью как характерологической особенностью всей культуры начала XX века, когда дискурсивные взаимосвязи в словесном произведении основаны на взаимодействии семантических кодов других ви-дов искусств. В центре внимания автора - проблема визуализации вербального в семантической структуре автопортрета, когда подобно живописцу и фотографу женщина-автор конструирует новую визуальную риторику и сквозь зеркало портрета и объектива маркирует себя и опознает себя в Другом. Отсюда и приоритетные визуальные стратегии репрезентации автопортрета: 1 . Зеркало как метафора автобиографической памяти; 2. Зеркало фотообъектива и опознание себя в Другом.

Ключевые слова: автобиография, автопортрет, вербальное /визуальное, пластически-изобразительный портрет, «структуральная символика», зеркальная оптика, визуальная риторика, фотография, зеркало фотообъектива, перспектива, точка схода.

Признанной универсалией модернистской культуры является потребность в самоописании. Биографический текст знаменует стремление автора к обнаружению субъектности в диалоге с собой и другими. На эту семантическую двусмысленность нарративной идентичности в автобиографии обратил внимание Поль Рикёр, артикулируя идею «тождества» (тождественность самому себе во времени) и «самости» («я» сам). [1] «Я», таким образом,конституируется последовательностью субъективных идентификаций и саморефлексий: «Даже когда Ван 
Гог рисует стул, - замечает философ, - он изображает человека: он проецирует на полотно образ человека, т. е. того, кто этот мир представляет» [2]. Женская автобиография это не только осмысление персональной истории в «хронотопе субъективности» [3]. В отличие от повествователя-вуайера, стремящегося подсмотреть то, что скрыто и тайно, женщина создает свой тип биографического письма, публично обнажая сокровенные зоны интимного и исповедального опыта. Преодолевая культурно-антропологические ограничения и телесные табу, женщина артикулирует новую идентичность, не укладывающуюся в рамки дихотомии мужское / женское. [4] Элен Сиксу, размышляя о «женском письме» в статье «Хохот Медузы», обращается к женщинам с призывом: «Пишите себя, пишите собой!». Телесное письмо, когда тело вписано в текст, порождает новый телесный опыт вербальных и визуальных дискурсивных практик: «Женщина должна писать самое себя: должна писать о женщинах и привлечь женщин к процессу писания, от которого они были отторгнуты так же жестоко, как от собственного те-ла, по тем же причинам, с помощью тех же законов и с той же фатальной целью. Женщина должна вложить себя в текст - как в сущий мир и в человеческую историю - совершив самостоятельное движение» [5]

Телесное письмо, когда тело вписано в текст, порождает новый телесный опыт вербаль-ных и визуальных дискурсивных практик. Так в литературной феминистской критике [6] артикулируется гендерный подход к изучению женской автобиографии. В автобиогра-фическом письме женщина апеллирует к женскому телесному и сексуальному опыту, а специфика женской субъективности определяется как конвенция саморепрезентации женского «Я» и внутренней «аффектированной истории» [7]. Оставляя в качестве заметок на полях феминистский дискурс и гендерные исследовательские рефлексии, обратимся к морфологии автопортрета в структуре женской автобиографии Серебряного века. Автопортрет как пытливое всматривание автора в себя становится фактом самоидентификации и самопознания творца и соглядатая. Его архитектоника связана, с одной стороны, со становлением женской субъективности [8], когда женщина, находясь внутри мужской культуры, выражает себя через «курсив» и «дневники». С другой, - с интермедиальностью [9] как характерологической особенностью всей культуры начала XX века, когда дискурсивные взаимосвязи в словесном произведении основаны на взаимодействии семантических кодов других видов искусств [10]. Синтез нарративной и изобразительной авторепрезентаций, на наш взгляд, есть ключ к дешифровке автобиографического кода. Филипп Лежён, констатируя факт раннего осознания в истории искусства живописного портрета как жанра, сетовал на отсутствие исследований словесного портрета в автобиографии [11]. Нас же интересуют проблема визуализации вербального в семантической структуре автопортрета, когда подобно живописцу и фотографу женщина-автор конструирует новую визуальную риторику [12] и сквозь зеркало портрета и объектива маркирует себя 
и опознает себя в Другом. В связи со сказанным можно определить приоритетные, на наш взгляд, визуальные стратегии репрезентации автопортрета.

\section{Зеркало как метафора автобиографической памяти}

Метафора зеркальности как ведущего онтологического принципа заложена уже в античных мифах. Нарцисс, взглянув свое отражение, истаял от любви к самому себе. Персей, глядя на отполированную поверхность щита, убивает Горгону - чудовище, взгляд которого смертелен для человека. Гера посылает к маленькому Дионису-Загрею титанов, которые сначала завлекают его погремушками и зеркальцем в том числе, а потом убивают. Сердце Диониса-Загрея получает богиня - Рея ( Афина или Деметра), - и она складывает кусочки тела в ларец, после чего он «вновь возрождается к жизни». [13] В этих мифах обозначен амбивалентный характер зеркала, так как сам принцип зеркального отражения основан на принципе «сходства / подобия» и «различия». С одной стороны, человек видит свое отражение в зеркале - зеркального двойника. С другой, - он с древних времен устанавливает различие, понимая, что отражение в зеркале скрывает ровно столько, сколько показывает [14], что это оптическая иллюзия, о чем свидетельствует инверсия левого и правого. Зеркало как объект самопознания и нового рефлексивного опыта исследуется Ж. Лаканом в работе «Стадия зеркала как образующая функцию Я». Размышляя о роли зеркала в формировании ребенка, философ рассматривал зеркало как символическую матрицу - некую идентификацию и трансформацию, которая происходит с субъектом, когда он присваивает себе некий образ. Стадия зеркала - это важнейший момент в формировании структуры субъекта, первый набросок Я и зарождение опыта узнавания. Для Лакана важным представляется тот факт, что подобное узнавание фиксируется на стадии, когда ребенок способен идентифицировать себя в зеркале. Зеркало проявляет, делает очевидным процесс самопорождения через отношение к себе, своему телу, оформляющегося в целостное переживание. Здесь ребенок впервые узнает и навсегда признает свой образ, присваивая его только тогда, когда поверит, что этот образ его собственный, только ему принадлежащий:

«Это развитие, - замечает Лакан, - переживается как временная диалектика, решительно проецирующая формирование индивидуума в историю: стадия зеркала есть драма, (драма установления собственной идентичности -я) внутренний посыл которой стремительно развивается от недостаточности к опережению и которая для субъекта, пойманного на наживку пространственной идентификации, измышляет фантазмы, постепенно переходящие от раздробленного образа тела к форме, каковую мы назовем ортопедической для его целостности, - и , наконец, водруженным на себя доспехам некой отчуждающей идентичности, которая отметит своей жесткой структурой все его умственное развитие» [15]. 
«Я как другое» и «другое как я» - основа нарциссических отношений человека и его двойника. [16] Зеркальный нарциссизм проявляется в удовольствии созерцания своего зеркального отражения и обнаружении Другого в себе. Зеркало как метафора автобиографической памяти - глубинный слой воспоминания, след давно прошедшего времени: «Глубина зеркала сопоставима с глубиной памяти, -размышляет о нарциссизме и метафоре зеркала Е.Краснухина. - Их общая природа есть природа повторения. Память - это своеобразное зеркало, она отражает прошлое. Воспоминания представляют собой повторение чистого прошлого в настоящем. А зеркало, проецируя перед нами нарциссические объекты желания, превращает их в воспоминания в том смысле, что желание отсылает нас к прообразу и идеалу, к оригиналу чистого прошлого. Как и у зеркала, у памяти есть глубинная и поверхностная форма отражения. Поэтому говоря о нарциссизме зеркала и эротизме памяти, мы обнаруживаем две ее формы - припоминание смысла и навязчивый рефрен пустого означаемого». [17]

«Человек перед зеркалом» - универсальная метафора и в нравственной философии М.Бахтина. Ученый анализирует ситуацию зеркального отражения, в которой зеркало является своеобразным средством «самообъективации». Этот феномен связан с категориями «другого», выступающего фактически в качестве «я - двойника». Явление зеркальности, по мнению Бахтина, находит выражение в двух различных способах переживания себя: а) «примитивная позиция самосознания», созерцающего собственную наружность - «внешний» образ»; б) «самосознание» с позиций «Другого»: «Совершенно особым видением своей наружности, --комментирует Бахтин, - является смотрение на себя в зеркало [...]. Мы видим отражение своей наружности, но не себя в своей наружности, наружность не обнимает меня всего, я перед зеркалом, а не в нем [...]. В самом деле, наше положение перед зеркалом всегда несколько фальшиво, так как у нас нет подхода к себе самому извне, то мы и здесь вживаемся в какого-то неопределенного, возможного другого, с помощью которого мы пытаемся найти ценностную позицию по отношению к себе самому, из другого пытаемся мы и здесь оживить и оформить себя; отсюда то своеобразное неестественное выражение нашего лица, которое мы видим в зеркале и какого у нас не бывает выражения в жизни». [18]

По мысли Бахтина, задачей художника, работающего над автопортретом, и является «очищение экспрессии отраженного лица». [19] А это достигается при условии, когда авторитетный автор-художник побеждает художника - человека. Использование зеркала в жанре автопортрета, начиная с XY1 века, означало, что лицо каждого человека есть содержательный текст, достойный прочтения. Самопортретирование с помощью зеркала позиционируется как путь самопознания - пытливое всматривание в себя в зеркале зна-меновало процесс формирования новой оптики и изменения способа мирочувствования. [20] Зеркало обнаруживает скрытые следы и образы, сложную систему аллюзий и метафор, устанавливая семантическое тождество и новую знаковость. Зеркало и память работают на сопряженной 
территории отраженного воспоминания. Зеркало артикулирует идею семантического тождества, отражая «внешнего человека» [21] - память «визуально реставрирует прошлое», [22] стирая его границы. Зеркало в биографической прозе - не только метафора автобиографической памяти, но и скрытая подпись самого автора, анонимное участие которого проявляется в фиксации документального факта собственной жизни. Обратимся непосредственно к текстам. Перед нами - две разные стратегии авто-репрезентации через портрет. Основная задача Н.Берберовой - «найти структуру индиви-дуальной символики» [23] ( КМ : 264) ${ }^{1}$, установить « факт о познании себя и смотрении внутрь себя» (КМ: 29), «расшифровать смысл реальности внутри меня и во вне» (КМ: 104). Автобиография для писательницы это прежде всего «рассказ о себе» ( КМ : 29), отсюда три формы самонаблюдения: а) портрет как взгляд на себя со стороны; б) пластически-изобразительный автопортрет в пространстве зеркального отражения, в) «структуральная символика» ( метафора Берберовой) как отражение сущностного «Я». Сравним первые две:

«Читатель, может быть, уже видит перед собой строгое лицо, очки, усы, вставные зубы, седые, прямые, коротко остриженные на затылке волосы (редеющие на темени) и то скучное, толстое и действительно «вечное» перо, которое держит артрическая рука с синими жилами. Картина неверная. У меня не только нет усов, но и бровей-то немного. В юности у меня было лицо миловидное без всякого выражения, годам к сорока лицо сделалось худым и очень грустным. А теперь не мне судить, какое оно. Да, я и не очень сейчас помню его, когда пишу. Знаю только, что время поработало топором над моими чертами: оно отточило подбородок, обрисовало рот, подняло скулы, срезало щеки. Лоб стал твердым, и весь овал в своих тенях живет теперь жизнью куда более интенсивной, чем на ранних фотографиях. Но нос у меня до сих пор короткий». (КМ: 31)

Главный акцент в этом грустно-ироничном самоописании сделан на интенсивности внутренней жизни автора. Очень точное слово подбирает сама Берберова - «самоизменение» ( КМ : 31). Другая семантика портрета проявлена в « идее закрепленного изображения» [24], когда автор однажды видит свое отражение буквально: «я отразилась»- во время антракта в зеркале фойе театра Шан-з-Элиce : «Оно висит у лестницы, направо и в нем долго видишь себя, когда идешь по направлению к нему. Там, в глубине этого зеркала, я вижу себя в тот первый вечер, мое сине-голубое платье, с белыми кружевами, по тогдашней моде без рукавов и без талии, ноги в лакированных туфлях, узел волос на затылке, худые руки. Рядом со мной - Ходасевич» ( КМ: 255). Так устанавливается семиотическое равенство между наблюдателем и наблюдаемым, между автором текста и автором в тексте. Зеркало как визуальный текст в вербальном пространстве создает, по словам Лотмана, «эффект удвоения», когда зеркальная оптика меняет перспективу

1. Здесь и далее в тексте используются следующие аббревиатуры с указанием страницы: КМ Берберова Н. Курсив мой. Автобиография. М.,Согласие, 1996; ДКС-Гильдебрандт-Арбенина О. Девочка, катящая серсо... Мемуарные записи. Дневники. М., Молодая гвардия, 2007. 
и точку зрения, трансформируя прежние культурные смыслы. [25] Важную роль в визуальном лаби-ринте автобиографической памяти и персональной символики играет миф о Товии и Ангеле [26]. Любимый сюжет в живописи эпохи Ренессанса для Берберовой - еще один способ самопортретирования. Идентифицируя себя то Товием, то с Ангелом, она видит двойственность в себе - разрыв, «шов», и в этом «походе маленького и большого» про-явлен, по словам автора, «феномен синтеза в мире антитез» ( КМ: 51 ): « Смотря на Товия, я вижу себя, внимательно несущую рыб, доверчиво марширующую вдоль низкого горизонта, раздва, раз-два, башмачки туго зашнурованы, обруч держит мои волосы, чтобы их не растрепал ветер. И я смотрю на Ангела, и тоже вижу себя: сандалии ловко обхватывают мои ноги, широкие лопасти одежды вьются вокруг моих бедер, лицо обращено вперед, словно у той фигуры, которую ставят, вырезанную из дерева, на бушприт корабля, идущего в далекое странствие, - и которая есть самый яркий и постоянный образ моей личной символики. [...] Товий - это все, что во мне боится и неуверенно, не смеет, не знает, все, что ошибается, сомневается, все, что надеется, все, что болеет и тоскует. А Ангел, в полтора раза больше человеческого роста, это все остальное, куда входит и восторг жизни, и чувство физического здоровья, и равновесие, и моя несокрушимость, и отрицание усталости, слабости, старости. (КМ: 253-254)

\section{Зеркало фотообъектива и опознание себя в Другом}

В мемуарах и дневниках Ольги Гильдебрандт- Арбениной встречаем другую стратегию автопортретирования, так как воспоминания для нее - это прежде всего рассказ о Других. Берберова стремится рассказать о себе и познать смысл собственной жизни, отсюда - скорее мужской, аналитический взгляд на мир и позиционирование себя как «внутреннего» зрителя. Ольга Гильдебрандт- Арбенина - женщина-Муза: «атласная кошечка» ( Гумилёв), «гумилевская девушка»( Юркун), «мансардная муза» ( Мандельштам):« Я хотела быть Женщиной и Творческой силой» ( ДКС : 214), но «осталась тенью в чьих-то судьбах» (ДКС :175). Старость - это гадость, «но женщиной я перестала быть, художницей тоже, так что вывод ясен; для чего я нужна на свете?» (ДКС : 215). Зеркало для автора становится свидетелем увядающей красоты и уходящей молодости, поэтому слова « противно смотреть в зеркало» (ДКС: 214) читаются как приговор несложившейся судьбы. Женский автопортрет в мемуарах и дневниках Гильдебрандт- Арбениной конструируется в групповом портрете через оппозицию Я / Другие, а параллелизм вербального и визуального проявлен в иной визуальной метафоре - зеркало как глаз фотообъектива. На аутентичность фотографии и портрета указывал Ю.Лотман в работе «Портрет», написанной в 1993 году: « Портрет, - писал он, - живопись, которая выполняла функцию фотографии тогда, когда фотография еще не 
была изобретена [...]. Собственное имя колеблется между фотографией и портретом, и это находит отражение не только в мистической, но и в юридической идентификации человека и его портрета» [27]. Фотография, таким образом, разрушив традиции миметической эстетики, стала отвечать новым потребностям визуальной репрезентации, которая раньше удовлетворялась с помощью зеркала и живописного портрета, а «фотоаппарат стал осознаваться рядоположенным кисти живописца, перу поэта и резцу скульптора» [28].

Автопортретные характеристики в мемуарном тексте - это краткие визуальные хро-ники, фиксирующие конкретное мгновение: «Когда фотограф наводит видоискатель, линия прицела проходит через его глаз, голову и сердце [...]. Фотографирование - это мой альбом для эскизов», - размышлял о фотографии Анри Картье-Брессон [29]. Гильдебрандт-Арбенина, подобно фотографу, вооруженному камерой, предоставляет читателям документальные свидетельства своей прекрасной юности. В отличие от ее картин, воспроизводящих ее раннее детство ( « Мои картины - это я в детстве, в раннем» детстве »- ДКС : 214), в прозе мы видим ее портреты в период расцвета и знакомства с лучшими представителями Серебряного века - и они фотографически кратки: « Я выглядела пре-красно ( для себя - лучше нельзя); У меня была большая красивая шляпа с черной сморо-диной, очень естественной» (ДКС: 112); «У меня было белое легкое платье ( материал из американской посылки) и большая соломенная шляпа» (ДКС : 128). Как мы видим, главный акцент сделан на том, « как она выглядит» и как на нее смотрят окружающие, потому что самый важный зритель для нее - мужчина. [30] Зеркало фотообъектива - это глаза палимпсестной памяти. Стирая слой за слоем, автор апеллирует к реставрированному прошлому, частично мифологизированному. Сфотографировать - значит запечатлеть ре-альную историю, придать важность и ценность самому объекту. Именно поэтому любой портрет в определенном смысле это автопортрет фотографирующего [31]: «Фотографы, --комментирует С.Зонтаг, - описывают свою работу и как бесчисленное множество приемов освоения объективного мира, и как неизбежно солипсистское выражение отдельного «я». [....] Если фотография обращена к миру, фотограф мало что значит, но если она - орудие бесстрашной воплощающей субъективности, фотограф - это все». [32] Конструирование женского автопортрета в тексте «Девушка, катящая серсо...» происходит и посредством группового портрета. Визуальная риторика здесь иная. Помещая себя в центр, сопоставляя и сравнивая себя с Другими, Гильдебрандт фиксирует опыт самоидентификации: «Я была очень молода, но по странному совпадению моей судьбы уже пережила и самое печальное в своей жизни - и довольно сильные радости, и увлечения, хотя меня строго держали, я много болела и много училась. Он (Гумилев) сказал мне потом, что сразу помчался узнавать, кто я такая. «Это сестра Бальмонта». Меня вечно путали с Аней Энгельгардт, хотя она и не была похожа со мной, - более темноволосая, кареглазая, с монгольскими скулами, более яркая и, с моей точки зрения, гораздо более 
хорошенькая! На Никса Бальмонта, ее брата, я скорее могла походить по краскам - он был рыжий, зеленоглазый, со светло-розовым лицом и с тиком в лице - последнее мне очень нравилось в нем [...]». ( ДКС : 100)

Так в автопортрете происходит открытие внешнего и «внутреннего ландшафта» [33] в зеркале отраженных воспоминаний. Женщина как автор и наблюдатель дистанцируется от прошлого, создавая подобие линейной перспективы, рассчитанной на оптическую смену точек зрения и создание иллюзии трехмерной глубины. Зеркало и перспектива, образуя неразрывную пару со времен Леонардо да Винчи, Альберти, Брунеллески и др., воплощая новое символическое [34] и пространственное видение, позволяли автору автобиографии найти точку схода на линии горизонта, когда глаз, подобно движению объектива, визуально реставрировал не только прошлое автора, но находил след - оттиск его пребывания в биографии Другого. В этой располагающейся в бесконечности точке схода или «исчезающей точке » (от анг. - vanisghing point) прошлого происходит минутная встреча на похоронах Гумилева двух героинь - Нины Берберовой и Ольги Гильдебранд-Арбениной, которая описывает эту встречу очень лаконично: «Я почему-то помню подошедшую и вставшую рядом со мной Берберову - я ее не знала, - мы были одного роста и в одинакового цвета пальто - бардо- то, что заставляет думать, что действительно было холодно - в драповом пальто?». (ДКС : 151)

\section{ПРИМЕЧАНИЯ И БИБЛИОГРАФИЧЕСКИЕ ИСТОЧНИКИ:}

1. О приоритете «Я» в концепте «Я другой» философ писал: « [...] чтобы иметь перед собой «другого», отличного от «я», необходимо, чтобы существовало само «я» - П.Рикёр Конфликт интерпретаций. Очерки о герменевтике ( Перв с франц. И.Вдовиной). М.: «КАНОН»- пресс-Ц, «Кучково поле», 2002, с. 331;

2. П.Рикёр . Герменевтика и психоанализ. Религия и вера. М., Изд-во «Искусство», 1996, c. 18 ;

3. К.С.Пигров. Личный дневник как философско-антропологический концепт. // Сила простых вещей. / Сб. статей под ред. С.А. Лишаева.СПб., Алетейя, 2014, с.218;

4. См. об этом подробнее: И.А. Жеребкина. Феминистская теория 90-х годов: проблематизация женской субъективности // Введение в гендерные исследования. Ч. І: Учебное пособие / Под ред. И. А. Жеребкиной - Харьков: ХЦГИ, 2001; СПб.: Алетейя, 2001, с. 49-79.

5. Э.Сиксу. Хохот Медузы// Введение в гендерные исследования.Ч.2: Хрестоматия / Под ред. С.В.Жеребкина- Харьков ХЦТИ, СПб. Алетейя, 2001, с. 799

6. К наиболее известным методологическим работам по теории «женской литературы» относятся работы: Мэри Эллманн «Думать о женщинах», 1968; Эллен Моэрс «Лите-ратурная женщина», 1976; Сандры Гилберт и Сюзан Губар «Безумная на чердаке: женщина-писательница и литературное воображаемое в XIX веке», 1979; Рэйчел Дю Плесси «Письмо и несть ему конца: нарративные стратегии в женской литературе XX века, 1985»; Элейн Шоуолтер «Их собственная литература: британские женщины-писательницы от Бронте до Лессинг, 1977; сборники «Новая феминистская критика. Эссе о женщинах, литературе и теории» (1985), «Эти современные женщины: автобиографические эссе 20-х годов» (1978) и «Дочери декаданса. Женщины-писательницы на рубеже веков» (1984) под редакцией Элейн Шоуолтер. К работам по методологии «женского чтения» и «женского письма» относятся работы Торил Мой «Сексуальная / текстуальная политика: феминистская литературная теория», 1985; Мэри Якобус «Читающая женщина. Эссе о 
феминистском критицизме», 1986, а также книга под ее редакцией «Женское письмо и письмо о женщинах», 1979; Шошаны Фельман «Чего хочет женщина? Чтение и сексуальное различие», 1993, Алис Жарден «Gynesis: Конфигурации женщины и современность», 1985; книга под редакцией Нэнси Миллер «Поэтика гендера», 1986; а также работы французских теоретиков Юлии Кристевой, Люси Иригарэ и Элен Сиксу. См. об этом подробнее: И. Жеребкина. Феминистская литературная критика // Электронный peсурс.: режим доступа: http://www.owl.ru/library/004t.htm. Дата обращения: 19.01.2019;

7. И.Жеребкина. Гендерная проблематика в парадигме культурных исследований. Элек-тронный ресурс: режим доступа http://sbiblio.com/BIBLIO/archive/usmanova_gender (Дата обращения 12.12.2018);

8. Новая философская конструкция субъективности и гендерная теория субъектности подробно анализируется в книге: И.Жеребкина. Субъективность и гендер: гендерная теория субъекта в современной философской антропологии. СПб., Алетейя, 2007;

9. См. подробнее о термине «интермедиальность» в статье А. Тимашков. К истории понятия интермедиальность в русской и зарубежной науке // Zmogus ir Zodis. Teoriniai klausimai, Helsinky,№11,2007. Сетевой ресурс: режим доступа: http://www.biblioteka. vpu.lt/zmogusirzodis/PDF/literaturologija/2007/tim21-26.pdf.(Дата обращения 11.01.2019)

10. Н. В. Тишунина в статье «Методология интермедиального анализа в свете междисциплинарных исследований» предлагает несколько определений. В узком смысле интермедиальность - это особый тип внутритекстовых взаимосвязей в словесном произведении, основанный на взаимодействии художественных кодов разных видов искусств. В широком - это создание целостного полихудожественного пространства в системе культуры. И более полное определение: интермедиальность - это «специ-фическая форма диалога культур, осуществляемая посредством взаимодействия художественных образов или стилистических приёмов, имеющих для каждой конкретной эпохи знаковый характер». Н.В. Тишунина . Методология интермедиального анализа в свете междисциплинарных исследований // Методология гуманитарного знания в преспективе XXI века / Материалы международной научной конференции. Серия «Symposium». Вып. № 12. СПб, 2001, с. 153.

11. Ф. Лежён. В защиту автобиографии. Эссе разных лет. /Пер. и вст. Б. Дубина // Ино-странная литература, 2000, № 4. Сетевой ресурс: режим доступа: http://magazines.russ.ru/ inostran/2000/4/lezhen.html (Дата обращения. 3.01.2019)

12. С эти термином, на наш взгляд, прекрасно работает М.Гришакова, анализируя прозу В.Набокова. // М. Гришакова. Визуальная риторика В.Набокова. /НЛО, 2002 № 54, с.208-264;

13. «Эпикуреец Филодем, современник Цицерона, пишет о трех рождениях Диониса: первом - от своей матери, втором - из бедра Зевса, и третьем, состоявшемся, когда Рея сложила куски его растерзанного титанами тела, после чего он вновь вернулся к жизни». // Мирча Элиаде. История веры и религиозных идей. Том1. От каменного века до элевсинских мистерий. Глава 1У. Дионис, или возвращение блаженного Бога. М., Критерион, М., 2002.Сетевой ресурс: режим доступа: http://royallib.ru/read/eliade_mircha/istoriya_ veri_i_religioznih_idey_tom_1_ot_kamennogo_veka_do_elevsinskih_misteriy.html\#40960 (Дата обращения: 15.01.19)

14. См. подробнее об истории зеркала и его исторической семантике монографию Мельшиор - Бонне С. История зеркала/ Предисл. Жана Делюмо. Пер.с франц.. Ю.М. Розенберг. -М.: Новое литературное обозрение, 2006.

15. Ж.Лакан. Стадия зеркала . Сетевой ресурс: http://www.gumer.info/bibliotek_Buks/Psihol/ lakan/st zerk.php. (Дата обращения. 14.06.2019);

16. Ж. Лакан. Семинары. Кн. 2. М., Гнозис- Логос, 1999, с.141.

17. Е. Краснухина. Нарциссизм желания или метафора зеркала в философии.// Философия желания. Сб. статей / Под ред. И.В. Кузина. СПБ.: Изд-во Санкт- Петербургского Гос. Университета, 2005, с.12.

18. М. Бахтин Автор и герой в эстетической деятельности // Бахтин М.М. Работы 20-х годов. Киев, «Next», 1994, с. 113.

19. Там же, с. 114. 
20. Это заложено в семантике самого слова. Портрет ( от франц. portrait, от устар. portraire изображать): а) извлекать наружу, обнаруживать; б) изображать , портретировать, в) писать образами, создавать подобие. См. подробнее об этимологии слова «портрет» в работе Бакшеевой В.Н. Русский словесный портрет: лирика и проза конца XY111 - первой трети X1X вв. Диссертация...доктора филологических наук. М., 2000; Давлетова Альбина Робертовна. Эстетические версии женского портрета в рассказах 60-90-х годов XX века. Диссертация ... кандидата филологических наук : 10.01.01 Москва, 2007; Сравним с устарев., по Далю, портрет- подобен(ь), облик, образ, поличие, лик.

21. М.Бахтин. Автор и герой в эстетической деятельности, с.116.

22. М.Гришакова . О некоторых аллюзиях В.Набокова // Культура русской диаспоры: Набоков-100. М., 2000, с.28.

23. В тексте используются следующие аббревиатуры с указанием страницы: КИ - Берберова Н. Курсив мой. Автобиография. М.,Согласие, 1996; ДКС - Гильдебрандт-Арбенина О. Девочка, катящая серсо... Мемуарные записи. Дневники. М., Молодая гвардия, 2007;

24. Ю.И.Левин. Зеркало как потенциальный семиотический объект // Левин Ю.И. И-бранные труды. Поэтика и семиотика. М., школа «Языки и культура», 1998. с. 563;

25. «Однако зеркало может играть и другую роль: удваивая, оно искажает и этим обнажает то, что изображение, кажущееся «естественным», - проекция, несущая в себе определенный язык моделирования. Литературным адекватом мотива зеркала является тема двойника. Подобно тому, как зазеркалье - это странная модель обыденного мира, двойник - остраненное отражение персонажа. Изменяя по законам зеркального отражения (энантиоморфизма) образ персонажа, двойник представляет собой сочета-ние черт, позволяющих увидеть их инвариантную основу, и сдвигов $<\ldots>$, что создает поле широких возможностей для художественного моделирования». Ю. Лотман . Текст в тексте // Ю. Лотман.Статьи, заметки выступления. 1. Общие проблемы ис-кусства/ Ю.М.Лотман. Об искусстве. СПб., Искусство, 1998,с.433.

26. См. подробнее об этом: С.Бернен , Р.Бернен . Мифологические и религиозные мотивы в европейской живописи 1270-1700. СПб., Академический проект, 2000.c.234-236.

27. Ю.Лотман . Портрет // Статьи, заметки, выступления. 11. Изобразительное искусство / Ю.М.Лотман .Об искусстве. СПб., Искусство, 1998, с.500.

28. В.В. Нуркова. Зеркало с памятью. Феномен фотографии. Культурно-исторический анализ. М.: РГГУ,2006. С.125

29. А. Картье-Брессон. Воображаемая реальность. Эссе. - СПб.: Лимбус Пресс, ООО «Издательство К.Тублина», 2013,с.15.

30. Размышляя о функции зеркала в истории живописи, Дж.Бергер артикулирует идею женщины как объекта и зрелища: «Реальная функция зеркала была иной. Оно было нужно для того, чтобы женщина сама санкционировала отношение к себе как - главным образом и в первую очередь - к зрелищу». // Дж. Бергер. Искусство видеть / Пер. с англ. Е.Шраги.- СПб: Клаудберри, 2012.c.60.

31. С. Зонтаг. О фотографии. М.: ООО «Ад Маргинем Пресс, 2013.c. 161.

32. Там же.

33. Там же, с. 161.

34. О символическом характере перспективы см. Э. Панофски // Перспектива как символическая форма. СПб: Азбука классики, 2004. 